\title{
KAJIAN SOSIAL EKONOMI MASYARAKAT PESISIR (STUDI KASUS MASYARAKAT DI DAERAH PERIKANAN KELURAHAN KARANG ANYAR PANTAI)
}

\author{
STUDY OF COASTAL AREA SOCIAL ECONOMIC COMMUNITY (STUDY OF \\ COMMUNITY IN FISHERYS AREA KARANG ANYAR PANTAI)
}

Said Usman Assegaf

Universitas Borneo Tarakan

\begin{abstract}
Abstrak : Penelitian ini bertujuan untuk mengetahui kondisi sosial yang terdiri dari aspek pendidikan, aspek keragaman pekerjaan, dan akses kesehatan nelayan yang bermukim di wilayah pesisir kelurahan karang anyar pantai dan untuk mengetahui kondisi ekonomi yang terdiri dari tingkat pendapatan nelayan, pendapatan diluar usaha nelayan, dan pendapatan keluarga nelayan pada masyarakat nelayan yang bermukim di wilayah pesisir kelurahan karang anyar pantai. Hasil penelitian ini adalah disimpulkan bahwa kondisi sosial masyarakat dilihat dari yang memiliki pekerjaan sampingan sebanyak 26,67\%, aspek pendidikan dengan rata-rata tingkat pendidikan terakhir responden yaitu SD/Sederajat dengan persentase $70 \%$. Sedangkan presentase responden yang memanfaatkan puskesamas sebanyak 73,33\%.
\end{abstract}

Kata Kunci : Sosial Ekonomi, Masyarakat Nelayan, Pesisir

Abstract : This Research aim to to know the social condition consisted by the education aspect, aspect of keragaman work, and access the fisherman health living in region of coastal area of chief of village compose the coastal anyar and to know the economics condition consisted by the storey;level of fisherman earnings, earnings of outside effort fisherman, and earnings of fisherman family at fisherman society living in region of coastal area of chief of village compose the coastal anyar. Result of this research is concluded by that social condition of society seen from owning side job as much 26,67\%, education aspect with the mean mount the last education of responder that is Elementary School/ on an equal with the percentage $70 \%$. While presentase responder exploiting puskesamas as much $73,33 \%$.

Key Words: Social Economy, Fisher Society, Coastal Area

\section{LATAR BELAKANG}

Bangsa Indonesia menyatakan diri sebagai negara kepulauan (nusantara) yang disatukan oleh laut sebagai satu wilayah kedaulatan Melalui Deklarasi Djoeanda 1957. Satu dasawarsa kemudian, pada tahun 1967 substansi deklarasi ini menjadi konsep geopolitik bangsa Indonesia yang sekaligus menjadi landasan wawasan kebangsaan yang disebut dengan Wawasan Nusantara. Konsep Wawasan Nusantara selanjutnya ditetapkan oleh Majelis 
Permusyawaratan Rakyat ke dalam Garis-Garis Besar Haluan Negara (GBHN) tahun 1973-1978 sebagai modal dasar pembangunan nasional dan terus diperjuangkan untuk dapat diterima di dunia internasioanl. Berkat perundingan yang cukup panjang dan gigih, pada akhirnya Pesisir adalah wilayah yang unik, karena dalam konteks bentang alam, wilayah pesisir merupakan tempat bertemunya daratan dan lautan wilayah pesisir merupakan wilayah yang penting apabila ditinjau dari berbagai sudut pandang perencanaan dan pengelolaan. Transisi antara daratan dan lautan di wilayah pesisir telah membentuk ekosistem yang beragam dan sangat produktif serta memberikan nilai ekonomi yang luar biasa terhadap manusia. Sejalan dengan pertambahan penduduk dan peningkatan kegiatan pembangunan sosial-ekonomi, nilai wilayah pesisir terus bertambah. Konsekuensi dari Meminjam pemikiran Gus Dur, Mindset pembangunan ekonomi Indonesia lebih di dominasi cara berfikir continental ketimbang kelautan maupun maritim. Hegemoni cara berfikir continental ini telah mengingkari fakta empiris dan alamiah bahwa Indonesia sebagai Negara kepulauan yang $3 / 4$ wilayahnya berupa laut. Cara berfikir hegemonic ini telah berlangsung sejak era berkuasanya kerajaan Mataram yang mengalahkan Islam pesisir hingga berlangsung pada era Indonesia modern. (Apridar,2011).

Kota Tarakan merupakan kota yang dikelilingi oleh laut. Besarnya wilayah lautan Kota Tarakan tentunya menyimpan potensi sumber daya perikanan yang konsep negara kepulauan (archipelagic state principle) diterima oleh lembaga Perserikatan Bangsa-Bangsa (PBB) sebagai konsensus hukum laut internasional yang sekaligus mengakui konsep Zona Ekonomo (Wahyono SK, 2009).

tekanan terhadap pesisir ini adalah masalah pengelolaan yang timbul karena ketidak sepahaman pemanfaatan yang timbul akibat berbagai kepentingan yang ada di wilayah pesisir.

Secara teoritis ekonomi kelautan belum menjadi sebuah kajian khusus di Indonesia lebih dominan menyangkut ekonomi sumberdaya alam dan lingkungan. Amat kurang melihatnya dari aspek lain umpamanya, kesejahteraan hingga ekonomi maistream dengan berbgai pendekatan baik structur maupun neo struktural, liberal maupun heterodoks.

sangat besar baik perikanan laut maupun perikanan pesisir laut (berupa usaha budidaya air payau/tambak maupun budidaya air tawar/kolam). Kawasan pesisir pantai di Kota Tarakan mencapai \pm $70 \mathrm{~km}^{2}$ yang juga sangat mendukung pengembangan perikanan sebagai mata pencaharian masyarakat di Kota Tarakan.

\section{RUMUSAN MASLAH}

Berdasarkan latar belakang di atas maka rumusan masalah penelitian ini adalah :

1. Bagaimana kondisi sosial masyarakat pesisir yang terdiri aspek paendidikan, aspek keragaman pekerjaan, dan akses 
kesehatan nelayan yang bermukim di Kelurahan Karang Anyar Pantai

2. Bagaimana kondisi ekonomi masayarakat pesisir yang terdiri dari tingkat pendapatan usaha nelayan, pendapatan diluar usaha nelayan, dan pendapatan keluarga nelayan pada masyarakat nelayan yang bermukim di Kelurahan Karang Anyar Pantai.

\section{TUJUAN PENELITIAN}

Untuk :

Penelitian ini bertujuan

1. Untuk mengetahui kondisi sosial masyarakat pesisir yang terdiri aspek paendidikan, aspek keragaman pekerjaan, dan akses kesehatan nelayan yang bermukim di Kelurahan Karang Anyar Pantai

2. Untuk mengetahui kondisi ekonomi masayarakat pesisir yang terdiri dari tingkat pendapatan usaha nelayan, pendapatan diluar usaha nelayan, dan pendapatan keluarga nelayan pada masyarakat nelayan yang bermukim di Kelurahan Karang Anyar Pantai.

\section{METODE PENELITIAN}

\section{Lokasi dan Waktu Penelitian}

Penelitian ini dilaksanakan di Kota Tarakan, Provinsi Kalimantan Utara dengan memilih salah satu wilayah yang termasuk dalam permukiman daerah pesisir.

Metode Pengumpulan Data dan Analisis Data
Populasi penelitian ini adalah masyarakat nelayan yang bermukim di Kelurahan Karang Anyar Pantai. Berdasarkan data yang diperoleh, terdapat jumlah populasi masyarakat dengan pekerjaan pokoknya sebagai nelayan di Kelurahan Karang Anyar Pantai sebanyak 649 KK.

Metode yang digunakan untuk menentukan jumlah responden adalah metode acak sederhana dengan mengambil jumlah responden yang terpilih sebanyak 30 responden. Untuk aspek sosial digunakan analisis deskriptif, untuk Aspek ekonomi digunakan analisis pendapatan untuk menghitung pendapatan responden. Rumus yang digunakan sebagai berikut:

$\pi=\mathrm{TR}-\mathrm{TC}$

Dimana :

$\Pi=$ Pendapatan

TR = Total Revenue/Total

Pendapatan

TC = Total cost $/$ Total biaya

(Soekartawi, 1998).

Hasil analisis diatas kemudiakan akan dijelaskan secara deskriptif.

\section{HASIL DAN PEMBAHASAN}

\section{$\underline{\text { Identitas Responden }}$}

Identitas responden adalah ciri-ciri yang dimiliki oleh nelayan dalam hubungannya dengan kegiatan yang dilakukan, termasuk anggota keluarga, serta hal-hal yang berhubungan erat dengan perkembangan kegiatan yang dilakukan. Identitas nelayan yang dimaksud disini adalah menyangkut umur, pengalaman bekerja, 
pendidikan, dan jumlah tanggungan keluarga.

\section{Keadaan Umur Responden}

\begin{tabular}{lcr}
\multicolumn{2}{c}{ Umur nelayan penting } \\
artinya dalam & pembangunan \\
pertanian & sebab & umur akan
\end{tabular} mempengaruhi tingkat kemampuan fisik dan cara berfikir. Tingkat umur berpengaruh pada diri nelayan dalam melaksanakan kegiatan usahanya. Pada umumnya nelayan yang berumur muda dan sehat mempunyai kemampuan fisik yang lebih besar dari pada nelayan yang berusia tua. Nelayan muda juga cepat menerima hal-hal yang baru dianjurkan. Hal ini disebabkan karena nelayan yang berusia muda lebih berani menanggung resiko. Untuk lebih jelasnya mengenai keadaan umur nelayan responden dapat dilihat pada tabel diagram berikut:

Tabel 1 Keadaan Umur Responden

\begin{tabular}{|c|c|c|c|}
\hline No & $\begin{array}{c}\text { Kelompok Umur } \\
\text { Nelayan } \\
\text { (Tahun) }\end{array}$ & $\begin{array}{c}\text { Jumlah } \\
\text { Nelayan } \\
\text { (Orang) }\end{array}$ & Presentase (\%) \\
\hline 1 & $25-38$ & 13 & 43.33 \\
2 & $39-52$ & 12 & 40 \\
3 & $53-65$ & 5 & 16.67 \\
\hline \multicolumn{2}{|r|}{ Jumlah } & 30 & 100 \\
\hline
\end{tabular}

Tabel 1 diatas menunjukkan umur nelayan responden. Umur produktif yaitu 25 tahun keatas dengan jumlah nelayan 13 orang dimana pada umur ini sangat mudah untuk menerima inovasi teknologi dalam aktifitasnya sebagai nelayan. Sebaran umur responden adalah 2538 tahun sebanyak 43,33\%, $39-52$ tahun sebanyak 40\%, 53- 65 tahun sebanyak $16,67 \%$.

\section{$\underline{\text { Pendidikan Responden }}$}

Pendidikan pada umumnya mempengaruhi cara berfikir nelayan responden, dimana semakin tinggi pendidikan semakin cepat pula menerima inovasi - inovasi baru. Untuk mengetahui tingkat pendidikan nelayan responden dapat dilihat pada tabel berikut :

Tabel 2 Tingkat pendidikan Responden .

\begin{tabular}{|c|c|c|c|}
\hline No & $\begin{array}{c}\text { Tingkat } \\
\text { Pendidikan }\end{array}$ & $\begin{array}{c}\text { Jumlah } \\
\text { Nelayan }\end{array}$ & Presentase (\%) \\
\hline 1 & $\begin{array}{c}\text { Sekolah Dasar } \\
\text { (SD)/Sederajat }\end{array}$ & 21 & 70.00 \\
\hline 2 & $\begin{array}{c}\text { Sekolah } \\
\text { Menengah } \\
\text { Pertama } \\
\text { (SMP)/Sederajat }\end{array}$ & 6 & 20.00 \\
\hline 3 & $\begin{array}{c}\text { Sekolah } \\
\text { Menengah Atas } \\
\text { (SMA)/Sederajat }\end{array}$ & 3 & 10.00 \\
\hline \multicolumn{2}{|c|}{ Jumlah } & 30 & 100 \\
\hline
\end{tabular}

Pada tabel 2 menunjukkan bahwa keadaan tingkat pendidikan formal nelayan Responden. Rata-rata SD dengan jumlah 21 orang dengan persentase $70 \%$. Dengan melihat data tersebut dapat disimpulkan bahwa pendidikan nelayan responden masih sangat rendah untuk menerima teknologi dan inovasi.

\section{Pengalaman Kerja Responden}

$$
\text { Pengalaman }
$$

kerja responden sangat mempengaruhi pekerjaannya semakin banyak pengalaman yang dimiliki semakin banyak pula pengetahuan yang didapatkan dalam melakukan pekerjaannya. Untuk lebih jelasnya mengenai pengalaman responden dapat dilihat pada tabel berikut : 
Tabel 3 Pengalaman kerja

Responden

\begin{tabular}{|c|c|c|c|}
\hline No & $\begin{array}{c}\text { Pengalaman } \\
\text { Kerja Nelayan }\end{array}$ & $\begin{array}{c}\text { Jumlah Nelayan } \\
\text { (Orang) }\end{array}$ & Presentase (\%) \\
\hline 1 & $0-5$ Tahun & 12 & 40.00 \\
\hline 2 & 6-10 Tahun & 9 & 30.00 \\
\hline 3 & $11-15$ Tahun & 2 & 6.67 \\
\hline 4 & $16-20$ Tahun & 5 & 16.67 \\
\hline 5 & $>20$ Tahun & 2 & 6.67 \\
\hline \multicolumn{2}{|c|}{ Jumlah } & 30 & 100 \\
\hline
\end{tabular}

Tabel 3 terlihat bahwa pengalaman kerja responden rata rata 0-5 tahun dengan jumlah nelayan 12 orang dengan jumlah presentase $40 \%$ dan jumlah nelayan 6-10 tahun 9 orang dengan persentase yaitu $30 \%$.

\section{$\underline{\text { Jumlah Tanggungan Keluarga }}$}

\section{Tanggungan keluarga} nelayan adalah anggota keluarga yang dibiayai oleh keluarga, baik yang ada dalam satu atap ataupun berada di tempat lain. Jumlah anggota keluarga yang bekerja pada kegiatan sebagai nelayan dapat mempengaruhi tingkat produksi yang didapatkan. Jumlah tanggungan keluarga nelayan responden dapat dilihat pada tabel berikut :

Tabel 4 Jumlah tanggungan keluarga responden Responden

\begin{tabular}{|c|c|c|c|}
\hline No & $\begin{array}{c}\text { Tanggungan } \\
\text { Keluarga }\end{array}$ & Jumlah (Orang) & Presentase (\%) \\
\hline 1 & $0-2$ Orang & 8 & 26.67 \\
\hline 2 & 3-4 Orang & 10 & 33.33 \\
\hline 3 & 5-6 Orang & 9 & 30.00 \\
\hline 4 & 7-8 Orang & 1 & 3.33 \\
\hline 5 & 9-10 Orang & 2 & 6.67 \\
\hline \multicolumn{2}{|c|}{ Jumlah } & 30 & 100 \\
\hline
\end{tabular}

Tabel 4 terlihat bahwa jumlah tanggungan keluarga nelayan responden rata-rata 3-4 orang dengan persentse $33,33 \% /$ keluarga. Dapat dikatakan semakin banyak tanggungan keluarga semakin banyak pula kebutuhan keluarga yang akan dikeluarkan oleh nelayan responden.

\section{$\underline{\text { Kajian Sosial Masyarakat Nelayan }}$}

1. Keragaman pekerjaan

Keragaman pekerjaan adalah suatu keadaan yang dimiliki oleh sebuah keluarga dimana kepala keluarga, dan seluruh anggota keluarga yang termasuk usia produktif untuk melakukan usaha memiliki sebuah pekerjaan. Untuk menilai keragaman pekerjaan sebuah rumah tangga maka indicator yang digunakan adalah pekerjaan sampingan bagi kepala rumah tangga, pekerjaan isteri yang ikut bekerja dan anggota yang termasuk usia kerja. Untuk mengetahui kondisi keragaman pekerjaan rumah tangga nelayan responden disajikan pada tabel berikut :

Tabel 5 Keragaman pekerjaan responden

\begin{tabular}{|c|c|c|c|}
\hline No & Uraian & Jumlah Nelayan & Presentase (\%) \\
\hline 1 & $\begin{array}{c}\text { Responden Yang } \\
\text { Memiliki Pekerjaan } \\
\text { Sampingan }\end{array}$ & 8 & 26.67 \\
\hline 2 & $\begin{array}{c}\text { Jumlah Isteri Yang } \\
\text { Bekerja }\end{array}$ & 3 & 10.00 \\
\hline 3 & $\begin{array}{c}\text { Jumlah Anggota } \\
\text { Keluarga Yang Bekerja }\end{array}$ & 6 & 20.00 \\
\hline
\end{tabular}

Tabel 5 menunjukkan bentuk keragaman pekerjaan nelayan responden Yaitu responden yang memiliki pekerjaan sampingan, jumlah isteri yang bekerja serta jumlah anggota keluarga yang bekerja. Dari ketiga uraian diatas terlihat bahwa responden yang 
memiliki pekerjaan sampingan lebih dominan yaitu sebanyak 8 orang atau sebanyak Keragaman pekerjaan ini meliputi jenis pekerjaan seperti usaha kecil dan menengah. Dan untuk pekerjaan istri seperti bekerja di perusahaan udang. Sedangkan anak/anggota keluarga meliputi pekerjaan seperti nelayan.

\section{Akses Kesehatan}

Akses kesehatan sangat penting bagi sebuah rumahtangga, sebab keluarga yang sehat dapat menunjang dalam melakukan aktifitas usahanya. aksebilitas terhadap prasarana kesehatan seperti puskesmas. Untuk mengetahui aspek kesehatan bagi nelayan adalah sebagai berikut :

Tabel 6 Akses puskesmas responden

\begin{tabular}{|c|c|c|c|}
\hline No & Akses Puskesmas & $\begin{array}{c}\text { Jumlah } \\
\text { Nelayan }\end{array}$ & Presentase (\%) \\
\hline 1 & Memanfaatkan & 19 & 63.33 \\
\hline 2 & Belum Memanfaatkan & 11 & 36.67 \\
\hline \multicolumn{2}{|c|}{ Jumlah } & 30 & 100 \\
\hline
\end{tabular}

Tabel 6 menunjukkan bahwa jumlah rumahtangga nelayan responden yang memanfaatkan puskesmas cukup banyak dengan jumlah 19 rumah tangga atau sebanyak 63,33\%. Hal ini disebabkan karena adanya pelayanan kesehatan gratis sehingga masyarakat sudah tidak ragu untuk mengunjungi dan menggunakan fasilitas puskesmas.

Pada kajian social diatas dapat dilihat bahwa kajian social masih kurang ini dapat dilihat dari kergaman pekerjaan, akses pendidikan, dan akses kesehatan terutama pada aspek kesehatan. Masalah kesehatan tidak lepas dari aspek sosial, ekonomi dan budaya.

\section{Kajian Kondisi Ekonomi Masyarakat} Nelayan

1. Pendapatan Sebagai nelayan Pendapatan adalah hasil dari kegiatan yang diperoleh dalam berusaha baik berupa uang maupun barang dimana barang tersebut dihargai dengan nilai uang sehingga dapat dipergunakan untuk keperluan hidup. Sumber pendapatan dari nelayan yaitu pendapatan dari hasil bekerja sebagai nelayan.

Untuk mengetahui sumber pendapatan nelayan dari hasil tangkapan dapat dilihat pada tabel berikut :

Tabel 7 Tingkat Pendapatan Nelayan Responden

\begin{tabular}{|c|c|c|c|}
\hline No & Tingkat Pendapatan Nelayan & Jumlah & Presentase (\%) \\
\hline 1 & $1.000 .000-2.000 .0000$ & 14 & 46.67 \\
\hline 2 & $2.100 .000-3.000 .000$ & 11 & 36.67 \\
\hline 3 & $3.100 .000-4.000 .000$ & 2 & 6.67 \\
\hline 4 & $>4.000 .000$ & 3 & 10 \\
\hline \multicolumn{2}{|r|}{ Jumlah } & 30 & 100 \\
\hline
\end{tabular}

Tabel 7 menunjukkan bahwa tingkat pendapatan nelayan responden sebagai nelayan sebesar 1.000.000 - 2.000.000 dengan jumlah 14 orang atau sebanyak 46.67\%. Ini pendapatan mereka selama satu bulan. Pendapatan diatas adalah pendapatan bersih responden. Setelah dikurangi dengan biayabiaya pengeluaran, dapat dilihat pada Tabel berikut :

Tabel 8 Tabel Rata-rata Pedapatan dan Pengeluaran Nelayan 


\begin{tabular}{|c|c|c|c|}
\hline No & $\begin{array}{c}\text { Tingkat Total Pendapatan } \\
\text { Nelayan }\end{array}$ & Jumlah & Presentase (\%) \\
\hline 1 & $500.000-1.000 .000$ & 9 & 30.00 \\
\hline 2 & $1.100 .000-1.500 .000$ & 6 & 20.00 \\
\hline 3 & $1.600 .000-2.000 .000$ & 7 & 23.33 \\
\hline 4 & $>2.000 .000$ & 8 & 27 \\
\hline \multicolumn{2}{|c|}{ Jumlah } & 30 & 100 \\
\hline
\end{tabular}

Tabel 8 menunjukkan setelah melakukan pengurangan penerimaan dan pengeluaran dapat dilihat bahwa rata-rata penerimaan nelayan $500.000-1.000 .000$, Hal ini menunjukkan bahwa tingkat pendapatan nelayan responden sebagai nelayan Masih sangat minim.

2. Pendapatan sampingan nelayan Pendapatan selain nelayan adalah pendapatan nelayan responden yang didapat dari hasil bekerja sampingan diluar nelayan. Untuk mengetahui jenis pekerjaan lain nelayan responden dapat dilihat pada tabel 9 berikut:

Tabel 9 Tingkat pendapatan nelayan responden dari hasil pendapatan bekerja sampingan selain nelayan

\begin{tabular}{|c|c|c|c|}
\hline No & $\begin{array}{c}\text { Tingkat Pendapatan } \\
\text { Sampingan Nelayan }\end{array}$ & Jumlah & Presentase (\%) \\
\hline 1 & $\begin{array}{c}\text { Tidak Memiliki Pekerjaan } \\
\text { Sampingan }\end{array}$ & 22 & 73.33 \\
\hline 2 & $1.000 .000-2.000 .000$ & 6 & 20.00 \\
\hline 3 & $2.000 .000-3.000 .000$ & 2 & 6.67 \\
\hline \multicolumn{2}{|c|}{ Jumlah } & 30 & 100 \\
\hline
\end{tabular}

Tabel 9 Menunjukkan tingkat pendapatan nelayan responden dari hasil pendapatan bekerja sampingan selain nelayan . Masih rendah hal ini menunjukkan bahwa masih banyak responden yang tidak memiliki pekerjaan sampingan sebanyak 22 orang dengan persentase sebanyak 73,33\%. Dan jumlah pendapatan sampingan nelayan responden yang memiliki pekerjaan sampingan berkisar antara 1.000 .000 2.000.000 dengan jumlah persentase $20 \%$ atau sebanyak 6 orang. Dari hasil penelitian ini pendapatan yang diperoleh dari hasil bekerja sampingan dapat menambah biaya kebutuhan hidup rumahtangga responden.

\section{Pendapatan Istri Nelayan}

Untuk mengetahui pendapatan istri nelayan dapat dilihat pada tabel berikut :

Tabel 10 Pendapatan Istri Nelayan Responden

\begin{tabular}{|c|c|c|c|}
\hline No & $\begin{array}{c}\text { Tingkat Pendapatan Istri } \\
\text { Nelayan }\end{array}$ & Jumlah & Presentase (\%) \\
\hline 1 & Tidak Bekerja & 27 & 90.00 \\
\hline 2 & 2.000 .000 & 3 & 10.00 \\
\hline \multicolumn{2}{|r|}{ Jumlah } & 30 & 100 \\
\hline
\end{tabular}

Tabel 10 diatas dapat dilihat bahwa pendapatan isteri nelayan responden. Juga masih kurang hal ini dapat dilihat dari banyaknya istri nelayan yang tidak bekerja sebanyak 27 orang dengan persentase sebanyak $90 \%$. Adapun jumlah istri yang bekerja dengan tingkat pendapatan 2.000.000 sebanyak 3 orang dengan persentase sebanyak $10 \%$.

Banyaknya Istri responden yang tidak bekerja disebabkan minimnya keterampilan yang dimiliki, selain itu keterbatasan modal untuk bekerja juga menjadi kendala.

4. Pendapatan Anggota Rumah Tangga Nelayan

Pendapatan yang bersal daris upah/ gaji dan diperoleh dari hasil pendapatan yang lain. Untuk mengetahui pendapatan anggota 
rumahtangga nelayan responden Dapat dilihat pada tabel sebagai berikut:

Tabel 11 Tingkat pendapatan anggota rumahtangga nelayan responden

\begin{tabular}{|c|c|c|c|}
\hline No & $\begin{array}{c}\text { Tingkat Pendapatan Anggota } \\
\text { Keluarga Nelayan }\end{array}$ & Jumlah & Presentase (\%) \\
\hline 1 & Tidak Bekerja & 24 & 80.00 \\
\hline 2 & $1.000 .000-2.000 .000$ & 3 & 10.00 \\
\hline 3 & $2.000 .000-3.500 .000$ & 3 & 10.00 \\
\hline \multicolumn{2}{|c|}{ Jumlah } & 30 & 100 \\
\hline
\end{tabular}

Tabel 11 diatas dapat dilihat bahwa tingkat pendapatan anggota rumahtangga Nelayan. Juga masih sangat rendah karena masih banyak anggota rumahtangga responden yang tidak bekerja yaitu sebanyak 24 orang dengan persentase $80 \%$ Adapun jumlah anggota rumahtangga yang bekerja dengan tingkat pendapatan berkisar antara $1.000 .000-2.000 .000$ sebanyak 3 orang dan 2.000.000 - 3.500 .000 sebanyak 3 orang dengan persentase $10 \%$.

Hal ini menunjukkan bahwa anak - anak responden yang bekerja untuk membantu perekonomian keluarga hanya berjumlah 6 orang anak, ini terjadi dikarenakan banyak hal, diantaranya karena waktu untuk bekerja. ketika sudah mulai beranjak remaja rata - rata sudah pergi meninggalkan rumah untuk merantau sehingga intensitas waktu untuk membantu keluarga itu kurang, selanjutnya banyak juga yang menikah di usia mudah sehingga mereka bekerja tidak untuk membantu orangtua mereka tetapi untuk menghidupi keluarga mereka sendiri rata - rata anak responden sekolah sehingga sangat sedikit waktu untuk bekerja. ketika sudah mulai beranjak remaja rata - rata sudah pergi meninggalkan rumah untuk merantau sehingga intensitas waktu untuk membantu keluarga itu kurang, selanjutnya banyak juga yang menikah di usia mudah sehingga mereka bekerja tidak untuk membantu orangtua mereka tetapi untuk menghidupi keluarga mereka sendiri.

\section{KESIMPULAN DAN SARAN}

$\underline{\text { Kesimpulan }}$

Berdasarkan hasil penelitian maka kesimpulan yang dapat dirumuskan dari hasil penelitian ini adalah sebagai berikut :

1. Kondisi social masyarakat nelayan yang bermukim di pesisir pantai berdasarkan hasil persentase kajian social dapat disimpulkan bahwa kondisi social masyarakat dilihat dari yang memiliki pekerjaan sampingan sebanyak 26,67\%, aspek pendidikan dengan ratarata tingkat pendidikan responden yaitu $\mathrm{SD} /$ Sederajat dengan persentase $70 \%$. Sedangkan akses kesehatan, jumlah persentase responden yang memanfaatkan puskesmas sebanyak 73,33\%. Setelah melihat jumlah persentase tersebut, dapat disimpulkan bahwa kondisi social kecuali keragaman pekerjaan dan akses puskesmas, semuanya masuk kategori rendah. Sedangkan akses puskesmas termasuk tinggi, ini disebabkan karena adanya pelayanan gratis bagi 
masyarakat yang kurang mampu.

2. Kondisi ekonomi masyarakat nelayan yang bermukim di pesisir pantai masih sangat rendah. Hal ini dapat dilihat dari pendapatan kepala rumah tangga, pendapatan istri, dan pendapatan anggota rumah tangga yang masih sangat rendah.

$\underline{\text { Saran }}$

Diharapkan agar pemerintah lebih memperhatikan kondisi sosial ekonomi masyarakat pesisir sehingga msyarakat pesisir melalui fasilitas publik dan pelayanan kebutuhan dasar, bisa lebih meningkatkan pendapatan dan kesejahteraannya.

\section{DAFTAR PUSTAKA}

Victor P.H. Nikijuluw, 2001. Populasi dan Sosial Ekonomi Masyarakat Pesisir serta Strategi Pemberdayaan Mereka Dalam Konteks Pengelolaan

Yusuf, 2003. Pemberdayaan social ekonomi keluarga pada pemukiman kumuh di kelurahan lette Kecamatan Mariso Kota Makassar, Tesis PPS Unhas, Makassar.

Ishak Manggabarani,2016. Kajian Sosial Ekonomi Masyarakat Nelayan yang Bermukim di Pesisir Pantai (Studi Kasus Lingkungan Luwaor Kecamatan Pambang, Kabupaten Majene), Universitas Al Asyariah Mandar. 
